\title{
THOMAS HOBBES
}


Also by Johann P. Sommerville

POLITICS AND IDEOLOGY IN ENGLAND, 1603-1640

SIR ROBERT FILMER:

PATRIARCHA AND OTHER WRITINGS (editor) 


\title{
Thomas Hobbes
}

\section{Political Ideas in Historical Context}

\author{
JOHANN P. SOMMERVILLE \\ Associate Professor of History \\ University of Wisconsin-Madison
}




\section{(C) Johann P. Sommerville 1992}

All rights reserved. No reproduction, copy or transmission of this publication may be made without written permission.

No paragraph of this publication may be reproduced, copied or transmitted save with written permission or in accordance with the provisions of the Copyright, Designs and Patents Act 1988, or under the terms of any licence permitting limited copying issued by the Copyright Licensing Agency, 90 Tottenham

Court Road, London W1P 9HE.

Any person who does any unauthorised act in relation to this publication may be liable to criminal prosecution and civil claims for damages.

First published 1992 by

THE MACMILLAN PRESS LTD

Houndmills, Basingstoke, Hampshire RG21 2XS and London

Companies and representatives throughout the world

Copy-edited and typeset by Grahame \& Grahame Editorial, Brighton

ISBN 978-0-333-49599-5 ISBN 978-1-349-22131-8 (eBook)

DOI 10.1007/978-1-349-22131-8

A catalogue record for this book is available from the British Library 


\section{Contents}

Preface vii

List of Abbreviations ix

Chronology xii

1 Hobbes and his Context 1

1 Introductory 1

$21588-1640 \quad 5$

$3 \quad 1640-51 \quad 19$

$\begin{array}{lrl}4 & 1651-79 & 23\end{array}$

2 The Law of Nature and the Natural Condition of Mankind 28

1 Self-preservation 33

2 The state and right of nature 37

3 The laws of nature and justice $\quad 43$

4 Covenants 51

3 The Origins of Government and the Nature of Political Obligation $\quad 57$

1 The institution of a commonwealth 57

2 Conquest 63

3 The family and the state $\quad 70$

4 Political obligation $\quad 74$

4 Hobbes on Sovereignty and Law 80

1 Sovereignty $\quad 81$

2 The liberty and property of the subject 89

3 Law and the sovereign 96

4 The duties of the sovereign 100

5 Hobbes on Church and State 105

1 What is Scripture? 108 
vi

\section{Contents}

2 Ecclesiastical power: the case against

Bellarmine

3 Ecclesiastical power: De Cive, Leviathan and Anglican thinking

4 Excommunication and Erastianism

6 God, Religion and Toleration

1 God

2 Faith, salvation, revelation, prophecy and miracles

3 Toleration and conscience

4 Church history and reformation

Conclusion

Notes

Bibliography

201

Index 


\section{Preface}

This book is about the political ideas of Thomas Hobbes. Hobbes was a startlingly original thinker. I cannot say the same for myself. Many of my debts for particular points are recorded in the Notes and Bibliography. Tom Cogswell, Richard Cust, Sir Geoffrey Elton, Peter Lake, John Morrill, and Conrad Russell (Earl Russell) deserve thanks for answering my questions on Hobbes and his context, and more generally for guiding my thinking on early seventeenth-century English history. Mark Goldie, Quentin Skinner and Richard Tuck have heavily influenced my ideas on early modern political theory. All errors and misconceptions are, of course, my own.

The staffs of the British Library, Cambridge University Library, and Memorial Library here in Madison deserve thanks for their courtesy and efficiency. I am very grateful to the Graduate School of the University of Wisconsin at Madison, and especially to Jack Hexter and the John M. Olin Foundation, for funding my research and so enabling me to write this book. Patrick Riley deserves gratitude for making available to me his own set of Molesworth's edition of Hobbes' English Works, and for tactfully refraining from reminding me that I have not yet returned the books to him. I am very grateful to Quentin Skinner for sending me a copy of proofs of his pioneering essay on the relationship between Hobbes' political ideas and classical and Renaissance rhetorical theory ('Thomas Hobbes: Rhetoric and the Construction of Morality').

In the text below, dates are Old Style unless otherwise indicated, but the year is taken to begin on 1 January. I employ the term 'absolutist' 'to refer to accounts of political power which derive the ruler's authority either from a direct divine gift or an irreversible grant from the people', and which license the ruler to override all human laws in what he believes to be cases of necessity. This is Peter Lake's definition (Lake 1988, 7), and is (I think) how the word is generally used. 'Anglicans' are those who defended the government of the church of England as established after 1559. 'Laudians' are people who supported the policies of Archbishop William Laud; they commonly stressed the importance of sumptuous ceremonies in God's worship and rejected the idea that salvation and damnation 
viii Preface

are consequences of God's arbitrary decree. In the case of works which are available in many editions (e.g. Suarez's De legibus) references are generally given to the page numbers of a specified edition and also to book, chapter, and where appropriate section and subsection.

JOHANN P. SOMMERVILLE 


\section{List of Abbreviations}

Aubrey John Aubrey, 'Brief Lives,' chiefly of Contemporaries, set down by Aubrey, between the Years 1669 \& 1696, edited by Andrew Clark, 2 vols, Oxford 1898.

AW

Thomas Hobbes, Thomas White's "De Mundo" examined, translated by Harold Whitmore Jones, Bradford 1976. The original Latin was published in Thomas Hobbes: Critique du "De Mundo" de Thomas White, edited by Jean Jacquot and Harold Whitmore Jones, Paris 1973. References are to chapter and section, and to the folios of the original manuscript, which are printed in both the edition of the Latin text and in the English translation. Quotations are from the English translation.

Beh Thomas Hobbes, Behemoth or the Long Parliament, edited by Ferdinand Tonnies, 1889; second edition, with an introduction by Stephen Holmes, Chicago 1990.

B.L. British Library

CM Cornelis de Waard and others, eds, Correspondance $d u$ P. Marin Mersenne, Paris, 17 vols, Paris 1932-88. Where appropriate, references are to the second, revised edition.

DC Thomas Hobbes, De Cive. First published at Paris in 1642 under the title Elementorum Philosophiae Sectio Tertia De Cive. A revised and expanded edition appeared at Amsterdam in 1647, entitled Elementa Philosophica De Cive. The standard modern edition is De Cive: the Latin version, edited by Howard Warrender, Oxford 1983. A rather inaccurate English version appeared at London in 1651 under the title Philosophicall Rudiments concerning Government and Society, and has been edited by Howard Warrender as De Cive: the English version, Oxford 1983; this version has commonly been ascribed to Hobbes himself, but as 
Richard Tuck and others have recently argued, there is strong evidence against this attribution: see e.g. Tuck, 'Warrender's De Cive', Political Studies 33 (1985), 308-15 at 310-12. References below are usually to chapter and section in Warrender's Latin version (e.g. DC2:6 refers to chapter 2, section 6), but occasionally to page number of editorial and supplementary materials (e.g. DC 60 refers to p. 60).

Dialogue Thomas Hobbes, A Dialogue between a Philosopher and a Student of the Common Laws of England, edited by Joseph Cropsey, Chicago 1971.

EL

Thomas Hobbes, The Elements of Law Natural and Politic, edited by Ferdinand Tonnies 1889; second edition with a new introduction by M. M. Goldsmith, 1969. References are to part, chapter, and section.

EW Thomas Hobbes, The English Works of Thomas Hobbes, edited by Sir William Molesworth, 11 vols, 1839-45.

HMC Historical Manuscripts Commission Reports.

Lev

Thomas Hobbes, Leviathan, edited by Richard Tuck, Cambridge 1991. References are to chapter, page number in Tuck's edition, and page number in the 1651 edition. For example, Lev 21: 148/110 refers to chapter 21 of Leviathan at p. 148 of Tuck's edition, and p. 110 of the 1651 edition. The page numbers of the 1651 edition are printed in square brackets in Tuck's edition, and also in the widely used but less accurate edition of C. B. Macpherson (Harmondsworth 1968).

LW Thomas Hobbes, Opera Latina quae Latine scripsit omnia, edited by William Molesworth, 5 vols, 1839-45.

SP State Papers.

ST Aquinas, St Thomas, Summa theologiae. References are to part, question and article.

STC A short-title catalogue of books printed in England, Scotland, \& Ireland and of English books printed abroad 1475-1640, ed. A. W. Pollard and G. R. Redgrave, revised by W. A. Jackson, F. S. Ferguson and Katharine F. Pantzer, 2 vols, 1976-86. 
Wing Short-Title catalogue of books printed in England, Scotland, Ireland, Wales, and British America and of English books printed in other countries 1641-1700, ed. Donald Wing, second edition, 3 vols, 1972-88. 


\section{Chronology}

1586-9 Publication of Robert Bellarmine's Disputationes de controversiis

1588 Birth of Thomas Hobbes. Defeat of the Spanish Armada.

1603 Hobbes goes to Oxford University. James I becomes King of England.

1606 Pope Paul V places Venice under Interdict and condemns the English oath of allegiance (which rejected the claim that popes were empowered to depose heretical kings). Controversy over the Interdict and the oath.

1608 Hobbes graduates from Oxford and takes service with the Cavendish family as a tutor and later secretary.

1610-15 William Cavendish (later second Earl of Devonshire) tours the Continent, accompanied by Hobbes.

1612 Publication of Francisco Suarez's De legibus ac Deo legislatore.

1618 Outbreak of the Thirty Years' War.

1621 Debate between the House of Commons and James I on parliamentary privilege.

1625 Death of James I. Succession of Charles I. Publication of Hugo Grotius' De jure belli ac pacis.

1626-7 Charles I raises extra-parliamentary funds (the Forced Loan) which Hobbes helps to collect in Derbyshire.

1627 Sermons justifying the Forced Loan by Robert Sibthorp and Roger Maynwaring.

1628 Parliament approves the Petition of Right, condemning the Forced Loan and other recent royal policies.

1629 Publication of Hobbes' translation of Thucydides.

1629-30 Hobbes travels on the Continent with the son of Sir Gervase Clifton.

1629-40 Charles I rules without Parliament. Development of Hobbes' scientific interests. 
1634-6 Hobbes tours the Continent with the third Earl of Devonshire, and associates with Marin Mersenne and his circle at Paris.

1637 Publication of Hobbes' $A$ brief of the art of rhetorick, summarising Aristotle's Rhetoric.

1637-8 Hampden's Case: the judges narrowly decide in favour of the legality of Ship Money.

1638-40 Scottish rebellion against Charles I.

1640 April: Charles I summons the Short Parliament to raise funds for war with the Scots.

May: Charles I dissolves the Short Parliament, which had voted him no taxes. Hobbes completes the Elements of Law natural and politic.

November: Under pressure from the victorious Scots, Charles I calls the Long Parliament, which begins constitutional reforms and attacks advocates of absolutist ideas. Hobbes flees for France.

1641 Execution of the Earl of Strafford, one of Charles I's leading supporters. Publication of Descartes' Meditations on first philosophy, including Hobbes' objections. Hobbes completes De Cive.

1642 Outbreak of Civil War in England. Publication at Paris of a small edition of De Cive.

1642-3 Hobbes writes a long reply to Thomas White's De Mundo.

1644 Royalist defeat at the battle of Marston Moor. William Cavendish (Marquis of Newcastle and a leading royalist general) flees for the Continent.

1645 Royalist defeat at the battle of Naseby.

1646 Civil War ends in defeat for royalists. Charles, Prince of Wales arrives at Paris, where Hobbes teaches him mathematics.

1647 Revised version of $D e$ Cive published in a large edition at Amsterdam.

1649 Execution of Charles I. Abolition of monarchy and the House of Lords. Establishment of a republic in England. 
1650 Adult males required to take an Engagement, promising obedience to the new republic. Controversy over the Engagement. Cromwell invades Scotland.

1651 April/May: Publication at London of Leviathan.

August: A Scots army invades England.

September: Cromwell defeats Charles II and the Scots at the battle of Worcester.

1651/2 (Winter) Hobbes excluded from exiled court of Charles II in France. Hobbes returns to England and submits to the republican government.

1655 Publication of De Corpore.

1657 Leviathan reported to a parliamentary committee 'as a most poisonous piece of atheism'.

1658 Publication of De Homine.

1660 Restoration of Charles II.

1666 Parliamentary proceedings threatening to condemn Hobbes for his religious views. Hobbes writes $A$ Dialogue between a Philosopher and a Student of the Common Laws of England (printed 1681)

1668 Revised Latin edition of Leviathan published at Amsterdam.

$1670 \quad$ Hobbes writes Behemoth (printed 1679)

1679 Death of Hobbes.

1683 Leviathan and De Cive condemned and burned at Oxford University. 